Title: Language-Literature Integration in High-School EFL Education: Investigating Students' Perspectives

Author 1 \& Corresponding author: Vander Viana

Affiliation: University of Stirling

Postal address: University of Stirling

Faculty of Social Sciences

Stirling

FK9 4LA

Scotland

Telephone number: +44 (0)1786 466271

E-mail address: vander.viana@ stir.ac.uk

ORCID identifier: 0000-0003-3079-4393

Twitter: @ vanderviana

LinkedIn: $\underline{\text { htps://uk.linkedin.com/in/vanderviana }}$

Biographical note: Dr. Vander Viana is a Lecturer in TESOL and Applied Linguistics and the Program Director of the PhD in TESOL Research at the University of Stirling. He is the co-founder/co-chair of the Corpus Linguistics in Scotland (CLiS) Network (www.stir.ac.uk/clis).

Author 2: Sonia Zyngier

Affiliation: Federal University of Rio de Janeiro

Postal address: Rua Marquês de São Vicente, 287/302

Gávea 
[Type here]

Rio de Janeiro

22451-045

Brazil

Telephone number: +552122590521

E-mail address: $\underline{\text { sonia.zyngier@gmail.com }}$

ORCID identifier: 0000-0002-6355-6407

LinkedIn: https://www.linkedin.com/in/sonia-zyngier-25a8908/

Biographical note: Dr. Sonia Zyngier is Adjunct Professor in Applied Linguistics at the Federal University of Rio de Janeiro, Coordinator of English as a Foreign Language at the CECIERJ Foundation in Rio de Janeiro, and Co-Editor of the Linguistic Approaches to Literature Series (John Benjamins, Amsterdam) (https://benjamins.com/catalog/lal). 
[Type here]

\title{
Language-Literature Integration in High-School EFL Education: Investigating Students' Perspectives
}

\author{
Vander Viana \\ University of Stirling
}

Sonia Zyngier

Federal University of Rio de Janeiro

The use of literature in English as a Foreign Language (EFL) environments has had a long and controversial history. Currently, literature has returned to the language classroom once similarities between literary texts and everyday communication have been identified. However, literature is generally approached in a reductionist way in which students are expected to extract information from texts rather than experience them (Nguyen 2016; Tomlinson 2003). The workshop investigated here innovates by engaging students in meaningful aesthetic creations. Our study contributes to research on an under-investigated topic, namely, the integration of literature in EFL education in a high-school context. It analyzes Brazilian students' perceived learning/teaching gains/losses empirically after their participation in a language-literature integrated workshop unit on iconicity. The findings of this rigorous qualitative bottom-up analysis show students' positive attitude, particularly regarding the teaching strategies, creative (or otherwise) exercises proposed, life and educational relevance of the workshop, and content/language learning. This article provides original empirical ground for the integration of language and literature in high-school EFL education, which stimulates autonomy and moves away from approaches where students tend to repeat interpretations validated by teachers or critics. Its significance expands beyond the focal country given that the improvement of students' literacy is a major need observed in several countries (e.g. United Nation's fourth development goal on 'quality education'). 
[Type here]

Language-literature integration, student perspectives, high school, English as a foreign language, language learning/teaching

\section{Introduction}

The use of literature in English as a foreign language (EFL) education has undergone changes over the years and may be characterized by three different moments. First, when EFL education targeted reading/translating, canonical literary texts were regarded as writing exemplars and 'model culture' sources (Howatt 1984). Studying EFL was 'a tedious experience of memorizing endless lists of unusable grammar rules and vocabulary and attempting to produce perfect translations of stilted or literary prose' (Richards and Rodgers 2001, 6). The second moment occurred when English turned into an international language. As a result, the quasi-missionary emphasis on cultural values shifted to the pursuit of large-scale teaching/learning methods. Audio-lingual and structural methods mushroomed, and literary texts - seen as irrelevant, linguistically difficult, and culturally distant - were discarded. The language-literature divide was consolidated (see Kramsch and Nolden 1994), and the assumption that literature should not be used in EFL prevailed (see Bataineh, Al Rabadi, and Smadi 2013; Paesani 2011). The third moment arrived when linguists and educators realized that literary works shared similar forms and patterns with everyday language communication (e.g. Carter and Nash 1990; G. Cook 1997; Hall 2001). Acknowledged as a rich source for language acquisition, literary productions were welcomed back into the EFL classroom in the understanding that 'L2 curricula that are stripped of any contact with literary texts are probably poorer than ones that capitalize on literature as a means of fostering student engagement' (Xerri 2019, xv). 
[Type here]

In 2007, the Modern Language Association (MLA) Ad-Hoc Committee on Foreign Languages issued a report advocating for a language-literature integrated curriculum. To observe the impact of this report, Paesani $(2011,173)$ carried out a survey of studies conducted in the US after its publication. In line with the MLA's scope, Paesani (2011) examined practices in Modern Foreign Languages (MFL), which included - but were not restricted to - English. She noted that, while the integration had started in higher education in the US, 'further research into language-literature instruction in precollegiate FL contexts is also needed' (Paesani 2011, 175).

The lack of empirical studies on the educational integration of language and literature is not exclusive to the US. For instance, Carter $(2007,11)$ warns about the need for 'verifiable evidence of classroom practice', and Fogal (2015) stresses the same scarcity in pedagogical stylistics. The present paper fills this research gap by examining a language-literature integrative pedagogical proposal in a high-school EFL environment. It also innovates by offering an evidence-based learning/teaching evaluation from the perspective of high-school students.

Our study focuses on a workshop based on the principles of Literary Awareness (LitAw) (cf. Chan 1999; Zyngier 1994), which aims at developing students' sensitivity to stylistic resources - both formally and functionally (see also Carter and Nash 1990; Hall 2001, 2014). Inspired by critical pedagogy (Freire 1973; Shor and Freire 1987), LitAw engages students in meaningful exploration of creative texts and fosters their development as reflective agents. Their views then become rich data for understanding how language and literature can merge effectively. 
[Type here]

In line with reader response theories, LitAw supports the centrality of the readers in textual interaction as proposed by Rosenblatt ([1938] 1995) (see also Fish 1980; Iser 1987; among others). As such, it departs from traditional approaches to literature in EFL where students are expected to extract information from literary texts (cf. Rosenblatt's ([1938] 1995) definition of 'efferent reading'). Instead, its proposed activities aim at experiential learning (see Tomlinson 1998) and include making connections (e.g. Exercises 1a and 2a in the Appendix), inferences (e.g. Exercise 3) and predictions (e.g. Exercise 4a); reflecting (e.g. Exercise 4c); and responding emotionally and aesthetically.

Studies on the application of LitAw to the high-school context have examined students' profiles, evaluation questionnaires, creative outputs and reflective reports to assess the suitability of the materials and to examine the experience from a pedagogical stylistics perspective (Zyngier and Viana 2016; Viana and Zyngier 2017, 2019). Here, we analyze students' reflective accounts to investigate the learning/teaching impact of this language-literature integrative approach to high-school EFL education. In order to situate the present research within the current literature, the next section reviews some of the empirical studies conducted so far.

\section{Previous Empirical Studies}

Several publications offer theoretical support for the use of literature in EFL education (e.g. Hall 2001, 2014, 2015; Zyngier 1994) and/or propose practical approaches (e.g. Bouman 1983; Carter and Goddard 2016; Carter and Long 1991; Toolan 1998). However, empirical analyses which evidence the benefits of the integration are scarce and scattered (e.g. Bataineh, Al Rabadi, and Smadi 2013; Bloemert et al. 2017). 
[Type here]

We argue that teachers need not only to learn how to work in an integrative model; they must also have at their disposal clear empirical evidence of its outcomes.

Reviews of empirical studies on the pedagogical language-literature integration reveal a bias towards higher education (Fogal 2015; Paran 2008). For example, Bataineh, Al Rabadi and Smadi (2013) observed how eight Jordanian university students performed communicatively once introduced to literature-based instruction. They collected data from pre-/post-intervention multiple-choice tests, classroom observations, interviews, journal writing, and role-play. The post-intervention results showed higher scoring in the tests and improvement on linguistic, sociolinguistic, discourse, and strategic competences. The researchers concluded that literature-based instruction 'constitutes a valid alternative in searching for authentic, contextualized, and functional language for EFL learners' (Bataineh, Al Rabadi, and Smadi 2013, 670).

In another study, Fogal (2010) observed 35 Japanese EFL undergraduates who worked with three short fictional texts under different teaching methodologies. From questionnaires and interviews, the author concluded that the participants felt more comfortable with a teacher-centered methodology but mostly when the teacher provided enough scaffolding so that they arrived at meta-cognitive awareness.

Also limited to higher education, Nguyen (2016) studied 48 undergraduates of English language teaching in Vietnam. Acting as an instructor in two different groups, the researcher developed a nine-week project which combined reader-response theory and social-constructivism with the teaching of literary texts in English. The participants answered a pre-intervention test to elicit their prior experience with literature in English and their course expectations. Their description and evaluation of the course as well as 
[Type here]

their perceived learning were collected through a post-intervention questionnaire at the end of the semester. Nguyen $(2016,184-185)$ concluded that the

teaching approach helped the students become more active and interactive, as well as more reflective and reflexive, in constructing their interpretations of literary texts [...]. On the other hand, the pedagogical change also subjected the students to the complexities of creating a new learning paradigm in a traditional context where the transmission and reception of objectified knowledge are still prevalent[.]

Nguyen (2016) noted that students' evaluation was rather contradictory: some were fascinated by the pedagogical approach while others became stressed due to the degree of uncertainty and unfamiliarity inherent to the project.

Looking for reasons why poetry teaching seems to be in decline, Xerri (2016) carried out a survey with 376 students preparing for pre-university matriculation examinations at a post-16 college in Malta. He also conducted semi-structured interviews with 15 students and 8 poetry teachers to examine how they positioned themselves in relation to poetry and its teaching. He concluded that the decline could be attributed to the fact that his participants did not read poetry for pleasure.

Turning to secondary education, Akyel and Yalçin (1990) examined literature teaching in five private schools in Istanbul. Two questionnaires - one answered by 22 teachers and the other by 150 students - were administered, gathering both groups' evaluation of the program, teachers' goals, students' reactions to the use of literature to develop linguistic and communicative competence, among other topics. This study led the researchers to propose some perhaps rather general recommendations such as a balanced selection of genres and a consideration of students' linguistic level. The value of this work, however, is that it does not rely solely on teachers' intuitive evaluations. 
[Type here]

The need to examine secondary-school students' perceived learning was also considered by Bloemert et al. (2017). Altogether, 635 Dutch students from 15 schools were asked one open question on the benefits of EFL literature lessons. The results revealed that students' perspectives differed among schools, but most participants considered literature as primarily instrumental to language learning. These results support Martin and Laurie's (1993) finding that students have a pragmatic attitude to literature.

Also within the context of secondary schools, Bloemert, Jansen and van de Grift (2016) asked 106 Dutch foreign language (FL) teachers to answer an online questionnaire on how they dealt with literature. The researchers found that the Dutch respondents differed widely in terms of approaches and amount of class time allotted for literature. They also noticed that curricular factors interfered more than teacher demographics when it came to choosing the approach.

In one of the most extensive research syntheses on the pedagogical languageliterature integration in foreign language contexts, Paran (2008) argues that this integration has not been fully accomplished and empirical studies remain minimal. School settings are overlooked and, in most cases, analyses focus on teachers' observations. He explains the preference for the university setting as a consequence of the access researchers have to this context and its easier ethical requirements (e.g. no need for parental agreement). Paran $(2008,490)$ concludes that research should examine 'how it [literature] is perceived by teachers and received by students, and how successful it is in promoting language proficiency. These school settings are, after all, the locus of most language learning in the world, and there are important aspects $[\ldots]$ that are still unexplored.' The study reported here addresses this gap. 
[Type here]

\section{Data Collection}

The workshop under focus was offered at a prestigious Brazilian federal high school located in an economically privileged area of a populous metropolitan city. This government-sponsored school aims at holistic education and fosters curricular interdisciplinarity while also preparing students for university entrance exams.

In order to cater for different proficiency language levels, high-school students in this context are divided into (i) those with no/little command of English and (ii) those who are able to communicate in this language. Group (i) has reading and grammar lessons while Group (ii) may join a thematic workshop. At the time of the study, LitAw was one of the workshop options. LitAw contemplates texts that stir students' imagination and feelings - from canonical poems to ads. The four traditional skills are practiced, but the emphasis is on reading and writing.

Each workshop unit contains four sections (see Zyngier and Viana 2016 for a detailed description). In 'Setting the scene', students are introduced to the topic inductively: they examine examples before being asked to explain the pattern under focus (see Appendix). This is followed by a summary of the main points in 'Food for thought'. The third section - 'Exploring possibilities' - encourages students to apply their knowledge to other contexts (e.g. ads and poems). 'Further explorations' is the most demanding section since it offers longer and more complex texts. Students are also invited to use the pattern under focus and explain the rationale for their creative writing.

The data presented here refer to the unit on iconic signs or the relation between the meaning of a word and how it is pictured on the page (Ljungberg 2016, 474). According to Carter and Goddard (2016), humans communicate by means of a semiotic system made of different signs, two of the major ones being the iconic and the symbolic. 
[Type here]

The authors explain that " $[a] n$ iconic sign tries to be a direct picture of what it refers to [...] A symbolic sign is not a picture of what is being referred to (the referent), but a picture of something that we associate with the referent' (Carter and Goddard 2016, 49; see also Goddard and Carey 2017). In a total of six 50-minute classes over three weeks, students worked with iconic words and short concrete poems, which did not overly challenge their linguistic proficiency level.

The workshop was offered to high-school students in three separate groups (each attended by 12-15 students) according to their schooling year (i.e. first, second and third), totaling 40 participants. To enable a demographic description, they were asked to complete a profile questionnaire, and 38 questionnaires were returned. ${ }^{1}$ Male participants outnumbered female ones (22 vs. 16), and age variation within groups was minimal, increasing per high-school year (from 15 to 17) as expected.

Students' self-reported formal English learning experience varied from none to 11 years of study at schools and private language institutes. This heterogeneity explains the diversity in their self-assessed command of English: from elementary to advanced in the first-year group and from intermediate to fluent among the second-year students. The third-year group evaluated their command in all the five pre-defined levels (i.e. from elementary to fluent). Unsurprisingly, second- and third-year students considered themselves more proficient than those in the first year. It is important to note here that, according to 2018 English Proficiency Index by Education First, Brazil has a low proficiency and it stands in the $53^{\text {rd }}$ position among 88 countries worldwide (see https://www.ef.co.uk/epi/regions/latin-america/brazil/). 
[Type here]

At the end of each workshop unit, students were asked to write a four-paragraph reflective account containing:

(1) a description of the unit,

(2) a description of selected class(es),

(3) an explanation for the selection in (2), and

(4) a discussion of the unit relevance.

Besides promoting students' critical sense (Freire 1998), the reflective accounts served as one of the evaluation tools. The grading rubrics consisted of clarity of meaning, structural accuracy, lexical adequacy, coherence, and mechanics. Each criterion was evaluated on a five-point Likert scale. The five individual results were added and multiplied by 0.4 so that the maximum final grade was 10 . The students were shown the rubrics and reassured that opinions would not be evaluated. The guidelines included positively and negatively worded questions (e.g. 'What did you especially like/hate about it?') to encourage sincerity.

The reflective accounts were submitted one week after the end of the unit and graded by the teacher. Disregarding non-submissions, the grades for the first unit averaged 7.96 (first year), 7.89 (second year), and 7.99 (third year), which can be considered high as the passing grade at this school is 6 . The following account illustrates how students felt confident to voice their opinion.

Another class [...] was the one that we had to look at book's covers and connect their displays to the reader's reactions. I did not like this class because in my opinion it was boring. We could do the same exercise but with books that are for our age, 
[Type here]

and it would be a lot better. I think it is possible to learn using topic that interest us, because the classes would be a lot more interesting and nice for us. ${ }^{2}[3 \mathrm{MI}]^{3}$

Although 3MI criticizes the materials selected, this negative evaluation did not affect her final grade (8.8). The account was well-written and addressed the points indicated in the rubrics.

From a total of 40 students, 28 submitted their reflective accounts on the first unit. Some students joined the workshop near the end of the unit and were not in a position to evaluate it fully; others decided not to submit the work and got a zero for this coursework component. These reflective accounts were used as research data in the present study, and they were analyzed as discussed in the following section.

\section{Data analysis}

Due to our focus on students' evaluation of their experiences, descriptive excerpts in the reflective accounts were disregarded. For example, 1SA writes that ' $[\mathrm{t}]$ he first unit that we study was on the form and the meaning, that is, the way where the drawings interact with the word and its meaning.' Although the sentence concerns the unit, nowhere does she position herself in relation to it. Consequently, this fragment was not coded. In the same paragraph, 1SA writes that 'I learned to perceive more what the author of the drawing, the designer, wants to pass, which is the message.' This fragment was coded as the student indicated what she had learned, evaluating the workshop usefulness. The iterative procedure adopted for data analysis is summarized in Figure 1. 


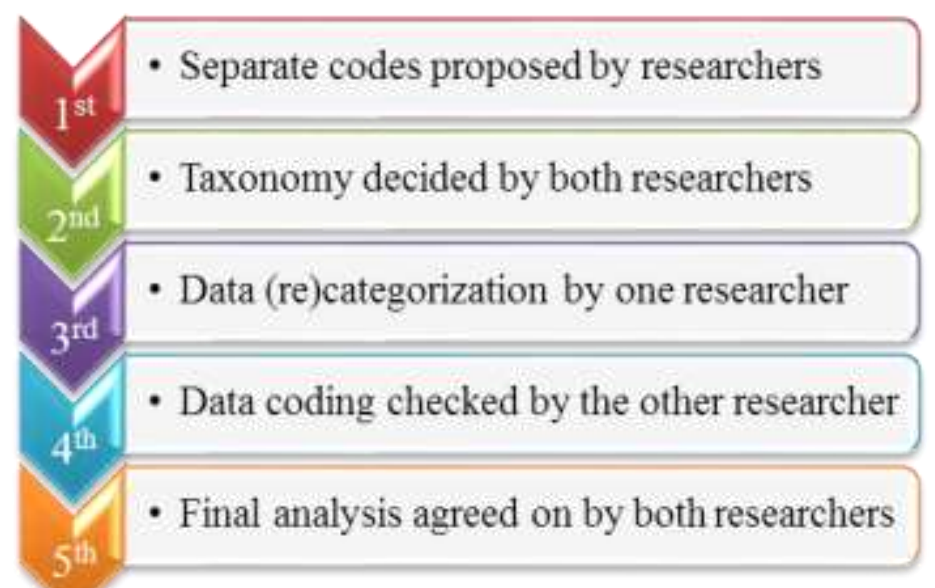

Figure 1. Data analytical steps.

First, both researchers suggested their own codes based on their individual analyses of the reflective accounts from one workshop group. After some discussion, they agreed on a taxonomy which included an identification of the themes (i.e. categories and subcategories) and of the values (i.e. whether the evaluation was positive or negative). One researcher later used the taxonomy to recategorize the data from that initial workshop group and to categorize the data from the other two. This procedure was conducted in NVivo 11 (QSR International Pty Ltd. 2015), a computer program for qualitative data analyses. In order to ensure the rigor of the analysis, the other researcher then checked all the coded data. Any potential discrepancies were discussed until a definitive agreement was reached.

The final taxonomy consisted of five main categories, two values and fifteen subcategories as detailed in Table 1. Only the 'students' category did not entail any subcategories. Given the overall infrequent number of fragments that deal with this 
[Type here]

topic, it made more sense to propose a single category with the usual two values (i.e. 'positive' and 'negative').

Table 1. Taxonomy and exemplification.

\begin{tabular}{|c|c|c|c|}
\hline Categories & Values & Subcategories & Examples \\
\hline \multirow{7}{*}{ 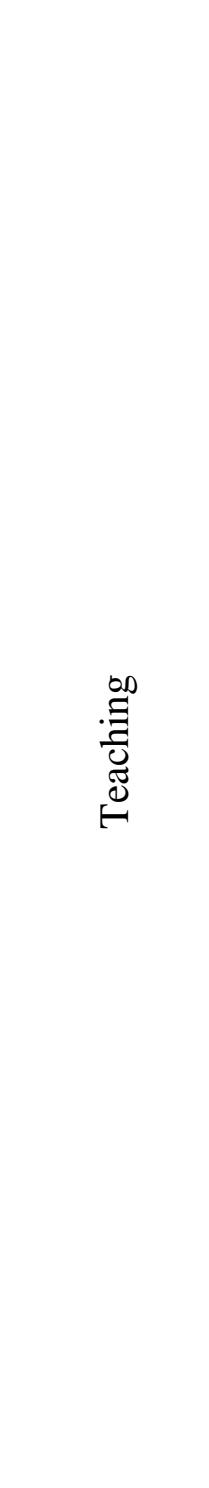 } & \multirow{3}{*}{+} & General & $\begin{array}{l}\text { 'In the paragraph above I've chosen not to } \\
\text { focus in any especial class because I } \\
\text { honestly liked all of them,' }[1 \mathrm{HJ}]\end{array}$ \\
\hline & & Strategies & 'The classes are very dynamic.' [1TG] \\
\hline & & Teacher & $\begin{array}{l}\text { 'the professor always helped us with any } \\
\text { problems' [3GR] }\end{array}$ \\
\hline & \multirow{4}{*}{ - } & General & $\begin{array}{l}\text { 'but as anything, some times it is very } \\
\text { boring,' [1SB] }\end{array}$ \\
\hline & & Management & $\begin{array}{l}\text { 'although we have not had much time to } \\
\text { work.' [3TF] }\end{array}$ \\
\hline & & Strategies & $\begin{array}{l}\text { 'but I think that if we could do it in groups } \\
\text { it would be even better.' [3MI] }\end{array}$ \\
\hline & & Teacher & 'The teacher was very strict,' [2BH] \\
\hline 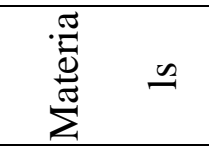 & + & Activities & 'It was great to discover those new \\
\hline
\end{tabular}




\begin{tabular}{|c|c|c|c|}
\hline & & & $\begin{array}{l}\text { statements and discover why the author } \\
\text { choose an specific book cover, we read } \\
\text { diferent texts and the diference between } \\
\text { those texts' [3SF] }\end{array}$ \\
\hline & & Creation & $\begin{array}{l}\text { 'I could make poems (witch is one thing } \\
\text { that I really like to do) in different ways.' } \\
{[2 \mathrm{PV}]}\end{array}$ \\
\hline & & General & 'I liked this unit.' [1RL] \\
\hline & & Language skills & 'it's great to write in English' $[1 \mathrm{HJ}]$ \\
\hline & & Topic & $\begin{array}{l}\text { 'This role unit works on an interesting } \\
\text { subject, that makes me think now twice } \\
\text { about the form and meaning.' [2PA] }\end{array}$ \\
\hline & & Activities & $\begin{array}{l}\text { 'pass three weeks doing the same type of } \\
\text { exercises is a bit boring' [2SV] }\end{array}$ \\
\hline & & Topic & $\begin{array}{l}\text { 'The unit was no big deal. We already } \\
\text { knew about it' }[2 \mathrm{AD}]\end{array}$ \\
\hline 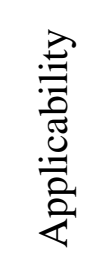 & + & Education & $\begin{array}{l}\text { 'Those classes would be acessible to all } \\
\text { the population, as way of help our current } \\
\text { situation of education's abandon,' [3NA] }\end{array}$ \\
\hline
\end{tabular}




\begin{tabular}{|c|c|c|c|}
\hline & & Life & $\begin{array}{l}\text { 'This unit was very important to my own } \\
\text { life. I started to pay more attention to the } \\
\text { images around me, trying to understand } \\
\text { what they mean and what they represent.' } \\
\text { [1TG] }\end{array}$ \\
\hline & & Work & $\begin{array}{l}\text { 'Thanks to it I saw a whole new working } \\
\text { market that I had never realized before.' } \\
\text { [3RA] }\end{array}$ \\
\hline & & Education & $\begin{array}{l}\text { 'and I guess it's not too important to my } \\
\text { education at all' [2AD] }\end{array}$ \\
\hline & & Life & $\begin{array}{l}\text { 'Probably, I won't use it very much in my } \\
\text { life,' }[1 \mathrm{MP}]\end{array}$ \\
\hline \multirow[b]{2}{*}{. } & \multirow[b]{2}{*}{+} & Collaboration & $\begin{array}{l}\text { 'We did lots of group works, and, because } \\
\text { of that, we were able to change } \\
\text { knowledge and learn much more.' [2BH] }\end{array}$ \\
\hline & & Content & $\begin{array}{l}\text { 'So, in this unit, I learned that the graphic } \\
\text { display of the words can be a very useful } \\
\text { resource, that is, I realized that the form of } \\
\text { the words can produce a strong effect in } \\
\text { the readers, contributing to the }\end{array}$ \\
\hline
\end{tabular}




\begin{tabular}{|c|c|c|c|}
\hline & & & $\begin{array}{l}\text { understanding not only of their meanings, } \\
\text { but of their main ideas.' [3JF] }\end{array}$ \\
\hline & & Language & $\begin{array}{l}\text { 'With all this, I also learned more } \\
\text { vocabulary.' [1TG] }\end{array}$ \\
\hline & - & Content & $\begin{array}{l}\text { 'As I'd already studied about this } \\
\text { [effectiveness of graphic display], it } \\
\text { hasn't been a new subject for me,' [2BH] }\end{array}$ \\
\hline & & $\begin{array}{l}\text { Lack of } \\
\text { assimilation }\end{array}$ & $\begin{array}{l}\text { 'Because of this the things that were there } \\
\text { to be learned were not assimilated.' }[2 \mathrm{CP}]\end{array}$ \\
\hline \multirow{2}{*}{ 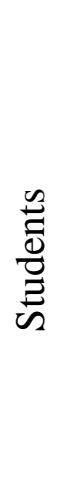 } & + & (None) & $\begin{array}{l}\text { 'and all of the students participated on the } \\
\text { discussions.' }[1 \mathrm{CD}]\end{array}$ \\
\hline & - & (None) & $\begin{array}{l}\text { 'But I am a little bit concerned about my } \\
\text { position in class, because I'm not a very } \\
\text { responsible student,' }[1 \mathrm{NM}]\end{array}$ \\
\hline
\end{tabular}

The coded excerpts were quantified in NVivo 11, allowing an overview of what the participants perceived as most (ir)relevant in the workshop unit, as will be discussed the following section.

\section{Results and Discussion}

A total of 266 different references (i.e. continuous textual sequences) were coded in the 28 reflective accounts. Table 2 shows the number of sources (i.e. reflective 
[Type here]

accounts) and references per subcategory, value and category. Moving away from pedagogical stylistics (Viana and Zyngier 2017), this study examines the data with a view to providing a fine-grained analysis of perceived learning/teaching gains and losses.

Table 2. Number of sources and references.

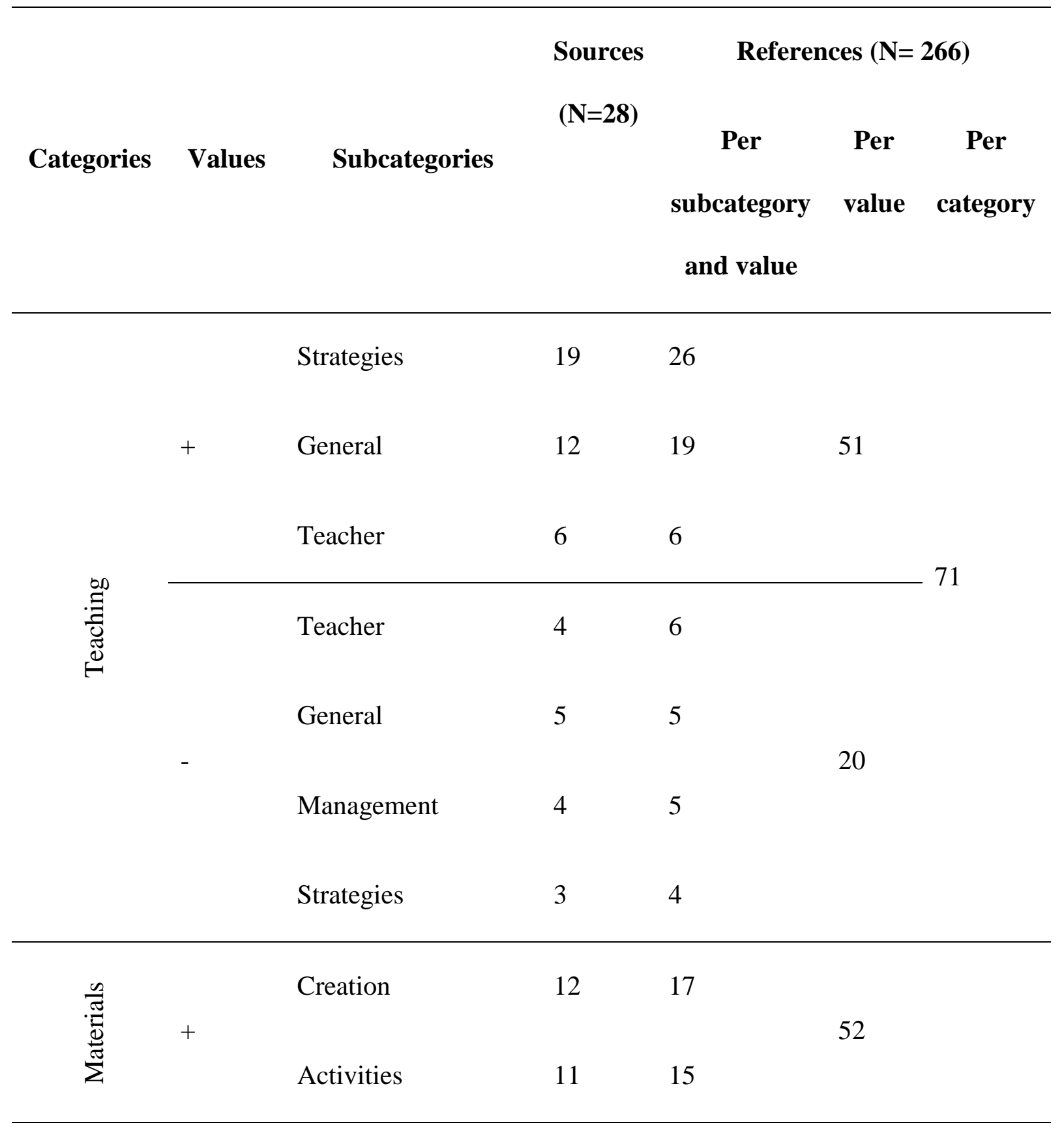


[Type here]

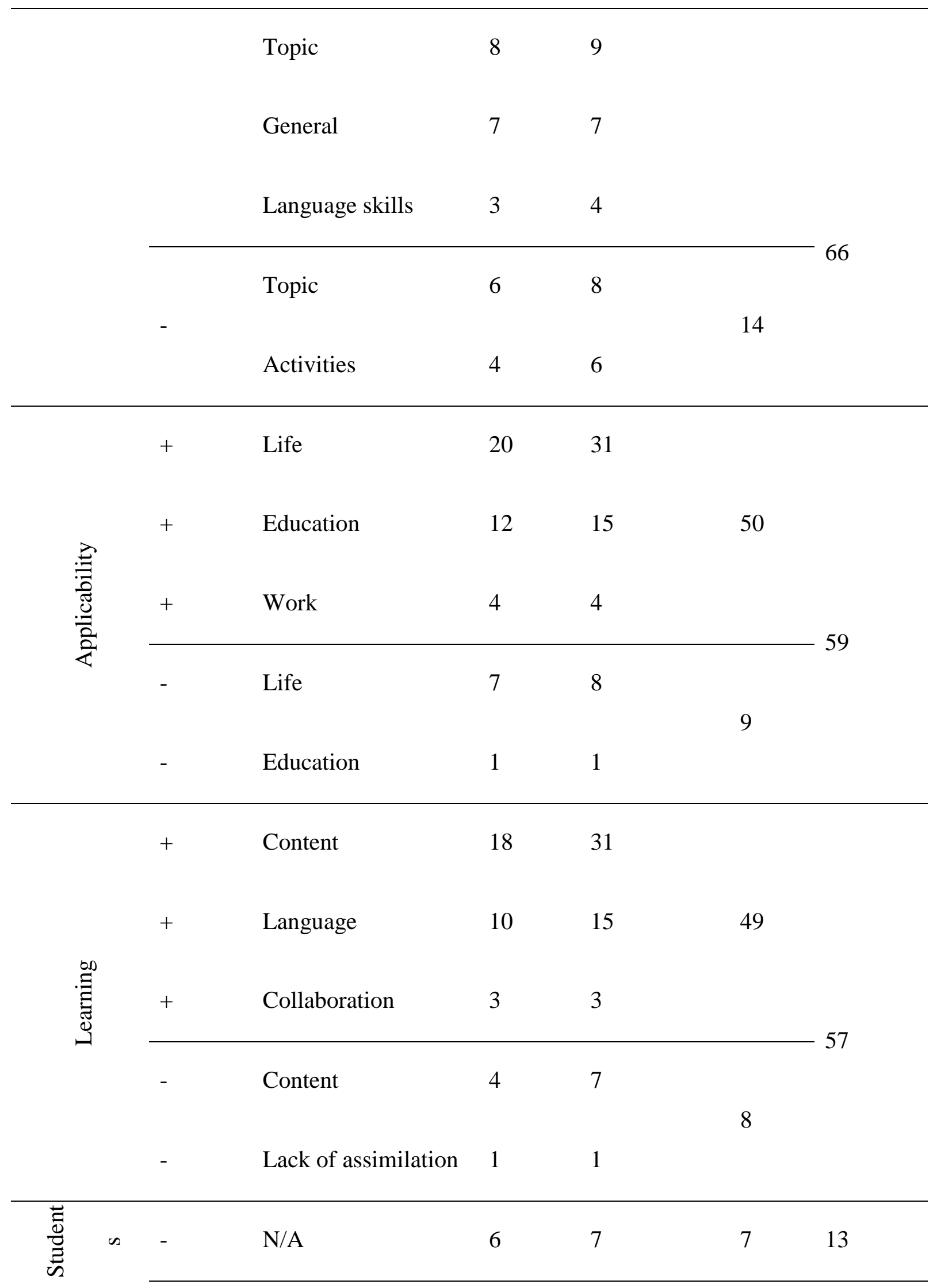


[Type here]

$+\quad$ N/A $\quad 6 \quad 6 \quad 6$

\section{1 'Value' findings}

Table 2 reveals that some of the subcategories have been evaluated from both a positive and a negative angle (e.g. 'general' within 'teaching'). This can be seen as a potential methodological strength as the students felt free to point out both advantages and disadvantages of the unit. In nearly all the cases of mirrored subcategories, positive evaluations outnumber negative ones with regard to references and sources, that is, more students praised (rather than criticized) the workshop, and they also did it more often within each of the reflective accounts.

While the fact that there are more positive than negative evaluations could be interpreted as a sign that the students did not feel so free to voice their criticism, two exceptions indicate the opposite. The participants' evaluations of themselves and of the teacher suggest that they were almost similarly appreciative and critical of the social actors in the workshops. Appraising the teacher is potentially more face-threatening than the other workshop aspects since the participants knew that the reports would be read by the teacher. This seems to reinforce the perception that they felt free to express their opinions. However, this suggestion cannot be categorically stated because the difference between negative and positive remarks consists of a single reference in the evaluation of students (seven negative evaluations vs. six positive ones), and there is a tie in the evaluation of the teacher (six positive and six negative instances). In the latter case, the criticism is not as well dispersed as the praise: the negative remarks are found in only 
[Type here]

four reflective accounts while each of the six positive references is found in a text written by a distinct student.

The most frequent subcategories (more than 13 references or 5\% of data) are all positive. The only main category which is not featured in the top results is the one dedicated to an evaluation of the students, which is infrequent overall. ${ }^{4}$

\section{2 'Teaching' findings}

The results reveal that the way the classes were conducted was one of the most memorable aspects since participants' evaluations focus mostly on teaching. Although this frequency could be misinterpreted as a preference for a teacher-centered model similar to Fogal (2010), the qualitative analysis shows that the students appreciated being able to take an active role in the classroom (cf. Freire 1973; Shor and Freire 1987).

The most frequent and dispersed subcategory in 'teaching' is 'strategies', which had also been identified - albeit not so prominently - in evaluation questionnaires (cf. Zyngier and Viana 2016). This subcategory includes references to the teacher's plan of action to assist learning. In the following excerpt, 2ST does not detail the strategies: she simply refers to class discussions, describing them as student-centered.

The classes are conducted in order not to make it so centred in the teacher. Then it has some space for the students to think and talk. We are always asked to discus and give our point of view about the exercise given [2ST]

Excerpts like this one illustrate students' enjoyment of the interaction facilitated by the teacher (see Benati and Angelovksa 2016; V. Cook 2016). The need to promote classroom interaction is not new (cf. Allwright 1984): this 'is where "learning" occurs and is also what prompts the linguistic behaviour needed for subsequent "development" 
[Type here]

to take place' (Ellis and Shintani 2014, 223). The data indicate that the students appreciated the strategies, avoiding 'boring and sleepy' classes (see also Nguyen 2016).

The second most frequent subcategory within 'teaching' presented general remarks (e.g. 'The classes were very good and very interesting' [3GR]). In this case, students' rationale for the positive evaluation is unclear. General comments seem to be rather recurrent, having also appeared in evaluation questionnaires (Zyngier and Viana 2016).

The most frequent negative evaluation in the 'teaching' category refers to the teacher, but only six references (out of 266) appear in four reflective accounts (out of 28). These negative remarks tended to focus on the teacher's personality and show how the students exerted their critical view.

it represented one of the things I must hate about the classes, the way the teacher cares for the student's opinions. [The teacher] seems to ignore everything that comes up that doesn't have a connection to what [the teacher]'s thinking [2LD]

If compared to 2ST's example, 2LD's fragment may lead to the wrong conclusion that these students attended different sessions; however, both belonged to the same secondyear workshop group. Contradictory evaluation of teaching was also found by Nguyen (2016), indicating that this concern is not restricted to the present research. Different and unfamiliar projects may cause uncertainty and be too challenging for some, causing negative reactions from students. However, the critical remarks were infrequent overall, 2LD's comment being actually the harshest. 
[Type here]

\section{3 'Materials' findings}

The frequent references to 'creation' within 'materials' show that language play was perceived as relevant to language learning (see also Bataineh, Al Rabadi, and Smadi 2013; G. Cook 1997; Ellis 2016). The materials were regarded as adequate means for exploring iconicity creatively (see Viana and Zyngier 2019 for detailed analyses of the poems) and helped the students 'to be comfortable and receptive to the input in their learning environment' (VanPatten and Williams 2015, 27).

The participants also highlighted the relevance of exercises other than those involving creativity. 'Activities' is one of the mirrored subcategories with both positive and negative remarks, but the former is at least twice as frequent as the latter. The excerpt below illustrates what was considered positive.

The most interesting class was the one about poetry. As I enjoy this style of writing even in Portuguese, I felt really comfortable with this subject in English. 'The Autumn Poem' was the text that gave us support to learn that topic, and it was very interesting how form and meaning can be connected even in poetry. [3TF]

Student $3 \mathrm{TF}$ comments on his engagement with written texts by focusing on a poem included in the material. He refers to his prior experience with poetry analysis in his mother tongue, an activity previously experienced by all participants. This interdisciplinary reference is relevant as the school where the study was conducted favored such cross-curricular links.

From a general perspective, not only did the students enjoy taking charge of their learning, but they were also happy with the deductive activities proposed. The exercises did not 'ask learners to read the text carefully and then answer comprehension questions on it' (Tomlinson 2003, 129). Instead, students praised the activities which encouraged 
[Type here]

them to put their creativity into practice and required the highest level of autonomy.

Their outputs evidence that they mastered the pattern presented and used it skillfully (see Viana and Zyngier 2019).

Negative evaluation of the materials was attributed mostly to the topic.

Mentioned only eight times in six reflective accounts, some resented the fact that they were already familiar with iconicity. This criticism appears in Viana and Zyngier (2017) and Zyngier and Viana (2016) and must be interpreted alongside the students' proficiency levels as their command of English varied dramatically. This reveals the difficulty of teaching a mixed-ability class, a context which 'deserve[s] far greater professional attention in ELT' (Hedge 2000, 25). The workshop should have addressed this issue by providing extra work for high-proficient students.

\section{4 'Applicability' findings}

The reflective accounts indicate that the workshop transcended the classroom. The most frequent subcategory within applicability reveals that students saw a positive impact of the experience in their lives: 'I used to judge the books by its covers, and now I have the fixed idea in my mind that these covers doesn't say anything about the book's quality, so I first search for some information about it.' [2SV]. This example shows how the workshop promoted students' perceived critical skill development (see also 3NA's and 1TG's quotes in Table 1).

An additional impact - of an educational nature - was also observed. Similar to 3TF (see Section 5.3), 1NM makes an interdisciplinary link: 'but I use a lot of things that I learn in a Biology activitie that we have to do a lot of posters, it was very useful'. Rather than associating two language subjects as 3TF did, 1NM makes a less usual 
[Type here]

connection between English and Biology. The direction of the relation also varies: while 3TF brought his prior learning to his English classes, 1NM applied what he had learned in English to another subject. The workshop therefore contributed to the school's emphasis on an interdisciplinary curriculum.

Despite the fact that 20 students identified positive applications of the workshop to their lives, this subcategory was also the most frequent negative one. Eight comments alluded to the fact that the perspectives of seven students did not change. While infrequent overall, the references reveal the importance of relating the work within the classroom to students' lives outside their classrooms.

\section{5 'Learning' findings}

Within 'learning', 'content' was the most frequent subcategory: the comments concentrated mostly on the topic of the unit. This subcategory had over four times more positive comments than negative ones (31 vs. 7). Students' dissatisfaction related frequently to their previous knowledge, the same reason identified in the negative evaluation of the materials. The positive remarks, however, showed different nuances:

In this unit we learn how the words can be written in different ways helping the readers to understand its meaning. We also learn how effective can be the graphic display of the words, the text itself, the images and book covers, if the readers can establish a relationship between them. The strategy has to be creative to call people's atencion. [3SM]

Here, 3SM highlights the central role of the reader. The excerpt shows that he grasped to a certain degree some of the tenets of literary awareness (Chan 1999; Zyngier 1994), reflecting on how language can be manipulated to draw attention. 
[Type here]

Realizing that the workshop was part of their EFL education, the students acknowledged how it could improve their proficiency. Such a positive relationship between the language-literature integration and proficiency improvement was noticed in Bataineh, Al Rabadi and Smadi (2013). Similarly, Bloemert et al. (2017, 12) stated that, to their participants, literature was 'a means of improving their language skills but they also, in varying degrees, indicate benefits related to the context, reader and text approach'. This student-perceived gain was the second most frequent subcategory within 'learning' and was only approached from a positive angle. The analysis shows that students do not only report vocabulary gains as they did in the evaluation questionnaires (cf. Zyngier and Viana 2016). Ten students believed that the workshop increased their language knowledge even in relation to aspects which were not being explicitly targeted like pronunciation.

\section{6 'Student' findings}

Students' self or peer evaluation totaled the least number of references, and the results show some balance between negative and positive evaluations with the former being slightly more frequent. The reflective accounts reveal participants' sense of belonging to a community of practice who contributed to the success or otherwise of the workshop. The following excerpt illustrates negative peer evaluation: 'but I also learned that [name] and [name] speak both too much and too loud' [3RA]. This male participant complains about the behavior of two female peers whom he regarded as too talkative, thus undermining his enjoyment of the workshop.

Positive evaluations provided an assessment of either future practice or past actions. For example, Student 1SJ assesses herself when she writes that 'I think with the 
[Type here]

time, I will be better and I will participate more too'. She also remarks on the novelty of the workshop dynamics to her, which she considered difficult but enjoyable. She acknowledged the learning potential of the strategies adopted in the workshop and promised to be more active.

\section{Concluding words}

The present study shows that a language-literature integrated pedagogical approach in high-school EFL education may lead students from merely reading EFL textbooks where 'the text has little impact on their [the students'] minds, their lives or their language acquisition' (Tomlinson 2003, 129) to experiencing an authentically meaningful event (Rosenblatt [1938] 1995). The findings support the design of EFL programs based on the consumption and production of imaginative texts, thus avoiding information-oriented models (Freire 1973; Nguyen 2016).

Besides contributing with a fresh pedagogical approach, this study is also original research-wise: it fills a gap in scholarly knowledge given the dearth of empirical research in the area. It evidences how the proposed LitAw unit on iconicity promotes high-school EFL students' sensitivity to creative texts at the same time that it helps students selfreflect on their educational experience. The participants welcomed this teaching strategy focused on interaction and freedom of expression. Going beyond what had been proposed, they operated in an interdisciplinary mode, applying what they had learned in the workshop to other subjects and vice-versa. The students perceived the workshop as both emotionally and cognitively engaging and realized benefits on several unexpected levels, including heightened critical awareness beyond the school walls. 
[Type here]

One of the major advantages of qualitative bottom-up analyses such as this one is their unanticipated findings. For example, the teacher/researcher in charge of implementing the workshop was diffident about its positive outcomes. The datagrounded results reveal that the issues in the teacher-student interaction were restricted to a few students. To most participants, the experience was educationally worthwhile and personally enjoyable. This conclusion could only be reached through a consistent and rigorous method of data analysis as detailed in this paper.

The workshop also overcame some local hurdles. In Brazil, there is a recurring public discourse of English not being learned in schools, particularly those that are government-sponsored (e.g. Perin 2003), as is the case in this study. There is also a widespread belief that students generally resent classes which focus on reading and writing (e.g. Jandre and Viana 2017). Neither of these ideas was borne out in the present study.

Although the study was conducted in Brazil, its significance extends beyond this country. It responds to one of the United Nation's sustainable development goals, namely, the one on quality education. The issue of low literacy levels is a topic of concern globally and one which needs to be tackled as soon as possible. The findings of the present investigation point towards ways where innovation in EFL literacy education may occur, and they reinforce the 2007 MLA recommendations that language and literature education should be integrated. This is true even in conservative educational settings where the curriculum is generally decided by national/local governments and/or relies mostly on the teaching of grammar, as is the case in Brazil (see also Nguyen 2016 in relation to Vietnam). According to 2PA, the workshop 'stimulated our [the students'] 
[Type here]

imagination and made us [them] deeply think about the form and meaning'. Indeed, the empirical evidence reported here shows that the student-centered LitAw workshop acted as an educationally refreshing experience.

\section{Acknowledgements}

We are grateful to the participants for their permission to use the data in this research, to $\mathrm{Dr}$ Juliana Jandre for her comments on Section 3 and to two anonymous reviewers for their feedback on an earlier draft of this paper.

\section{Notes}

${ }^{1}$ Two second-year students were transferred from another workshop at a later date and did not answer the profile questionnaire. We opted to describe all the participants because we see the workshop groups as communities of practice where all students contributed - in a way or another - to the learning/teaching environment.

${ }^{2}$ Data excerpts have not been edited.

${ }^{3}$ Reflective accounts are identified by three-digit codes where the number indicates the highschool year and the letters are used to identify the participants.

${ }^{4}$ Due to space limitations, our discussion will center on these most frequent subcategories. In order to provide a more rounded understanding of the participants' evaluation, we will also comment on the most frequent negative subcategory despite the fact that they do not meet the $5 \%$ cut-off point.

\section{References}

Akyel, A., and E. Yalçin. 1990. "Literature in the EFL Class: A Study of GoalAchievement Incongruence”. ELT Journal 44 (3): 174-180.

Allwright, R. L. 1984. “The Importance of Interaction in Classroom Language Learning”. Applied Linguistics 5 (2): 156-171.

Bataineh, R. F., R. Y. Al Rabadi, and O. M. Smadi. 2013. "Fostering Jordanian University Students' Communicative Performance through Literature-Based Instruction". TESOL Journal 4 (4): 655-673. 
[Type here]

Benati, A. G., and T. Angelovska. 2016. Second Language Acquisition: A Theoretical Introduction to Real World Applications. London: Bloomsbury.

Bloemert, J., E. Jansen, and W. van de Grift. 2016. "Exploring EFL Literature Approaches in Dutch Secondary Education”. Language, Culture and Curriculum 29 (2): 169-188.

Bloemert, J., A. Paran, E. Jansen, and W. van de Grift. 2017. 'Students' Perspective on the Benefits of EFL Literature Education". The Language Learning Journal: 114. doi:10.1080/09571736.2017.1298149.

Bouman, L. 1983. “Who's afraid of poetry?” Modern English Teacher 10 (3): 14-20.

Carter, R. 2007. “Literature and Language Teaching 1986-2006: A Review”. International Journal of Applied Linguistics 17 (1): 3-13.

Carter, R., and A. Goddard. 2016. How to Analyse Texts: A Toolkit for Students of English. New York: Routledge.

Carter, R., and Long, M. N. 1991. Teaching literature. London: Longman.

Carter, R., and W. Nash. 1990. Seeing through Language: A Guide to Styles of English Writing. Oxford: Blackwell.

Chan, P. K. W. 1999. "Literature, Language Awareness, and EFL”. Language Awareness 8 (1): $38-50$.

Cook, G. 1997. “Language Play, Language Learning”. ELT Journal 51 (3): 224-231.

Cook, V. 2016. Second Language Learning and Language Teaching. 5th ed. New York: Routledge.

Ellis, R. 2016. “Creativity and Language Learning”. In Creativity in Language Teaching: Perspectives from Research and Practice, edited by R. H. Jones, and J. C. Richards, 32-48. New York: Routledge.

Ellis, R., and N. Shintani. 2014. Exploring Language Pedagogy through Second Language Acquisition Research. London: Routledge.

Fish, S. E. 1980. Is There a Text in This Class? The Authority of Interpretive Communities. Cambridge, Mass: Harvard University Press.

Fogal, G. 2010. "EFL Literature Studies: Student Feedback on Teaching Methodology”. Asian EFL Journal 12 (4): 1-15. 
Fogal, G. 2015. "Pedagogical Stylistics in Multiple Foreign Language and Second Language Contexts: A Synthesis of Empirical Research”. Language and Literature 24 (1): 54-72.

Freire, P. 1973. Pedagogy of the Oppressed. Harmondswoth: Penguin.

Freire, P. 1998. Pedagogy of Freedom. Maryland: Roman and Littlefield.

Goddard, A., and N. Carey. 2017. Discourse: The basics. London: Routledge.

Hall, G. 2001. "The Poetics of Everyday Language”. CAUCE: Revista de Filología y su Didáctica 24: 69-86.

Hall, G. 2014. "Pedagogical Stylistics". In Routledge Handbook of Stylistics, edited by M. Burke, 239-252. London: Routledge.

Hall, G. 2015. "Recent Developments in Uses of Literature in Language Teaching". In Literature and Language Learning in the EFL Classroom, edited by M. Teranishi, Y. Saito, and K. Wales, 13-25. London: Palgrave Macmillan.

Hedge, T. 2000. Teaching and Learning in the Language Classroom. Oxford: Oxford University Press.

Howatt, A. P. R. 1984. A History of English Language Teaching. Oxford: Oxford University Press.

Iser, W. 1987. The Act of Reading. A Theory of Aesthetic Response. Baltimore: Johns Hopkins University Press.

Jandre, J., and V. Viana. 2017. "Student and Teacher Attitudes about English Education in Brazilian Public Schools". In TESOL Voices: Insider Accounts of Classroom Life - Secondary Education, edited by M. Dantas-Whitney, and S. Rilling, 93-99. Alexandria, VA: TESOL Press.

Kramsch, C., and T. Nolden. 1994. "Redefining Literacy in a Foreign Language”. Die Unterrichtspraxis 27 (1): 28-35.

Ljungberg, C. 2016. "Iconicity". In The Bloomsbury Companion to Stylistics, edited by V. Sotirova, 474-487. London: Bloomsbury.

Martin, A. L., and I. Laurie. 1993. "Student Views about the Contribution of Literary and Cultural Content to Language Learning at Intermediate Level". Foreign Language Annals 26 (2): 188-207. 
[Type here]

Modern Language Association Ad-Hoc Committee on Foreign Languages. 2007. Foreign Languages and Higher Education: New Structures for a Changed World. Accessed 20 November 2017. https://www.mla.org/Resources/Research/SurveysReports-and-Other-Documents/Teaching-Enrollments-and-Programs/ForeignLanguages-and-Higher-Education-New-Structures-for-a-Changed-World

Nguyen, H. T. T. 2016. "How Does an Interactive Approach to Literary Texts Work in an English as a Foreign Language Context? Learners' Perspectives in Close-up”. Innovation in Language Learning and Teaching 10 (3): 171-189.

Paesani, K. 2011. "Research in Language-Literature Instruction: Meeting the Call for Change?" Annual Review of Applied Linguistics 31: 161-181.

Paran, A. 2008. "The Role of Literature in Instructed Foreign Language Learning and Teaching: An Evidence-Based Survey”. Language Teaching 41 (4): 465-496.

Perin, J. 2003. “Ensino/aprendizagem de inglês em escolas públicas: Um estudo etnográfico”. [English Teaching/Learning at Public Schools: An Ethnographic Study]. Acta Scientiarum: Human and Social Sciences 25 (1): 113-118.

QSR International Pty Ltd. 2015. NVivo Qualitative Data Analysis Software. Version 11. Richards, J. C., and T. S. Rodgers. 2001. Approaches and methods in language teaching. 2nd ed. Cambridge: Cambridge University Press.

Rosenblatt, L M. (1938) 1995. Literature as Exploration. New York: Modern Language Association of America.

Shor, I., and P. Freire. 1987. A Pedagogy for Liberation: Dialogues on Transforming Education. New York: Bergin and Garvey.

Tomlinson, B. 1998. “And Now for Something Not Completely Different: An Approach to Language Through Literature”. Reading in a Foreign Language 11 (2): 177189.

Tomlinson, B. 2003. "Humanizing the Coursebook". In Developing Materials for Language Learning, edited by B. Tomlinson, 162-173. London: Continuum. Toolan, M. 1998. Language in Literature: An Introduction to Stylistics. London: Arnold. VanPatten, B., and J. Williams. 2015. "Early Theories in SLA". In Theories in Second Language Acquisition: An Introduction, edited by B. VanPatten, and J. Williams, 17-33. New York: Routledge. 
[Type here]

Viana, V. and S. Zyngier. 2017. "Exploring New Territories in Pedagogical Stylistics: An Investigation of High-School Students' Assessments". Language and Literature 26 (4): 300-322.

Viana, V. and S. Zyngier. 2019. "Creating writing and iconicity in English as a foreign language”. New Writing 16 (1): 38-49. doi:10.1080/14790726.2018.1476554.

Xerri, D. 2016. “'Living in a House Without Mirrors’: Poetry’s Cachet and Student Engagement”. Anglica: An International Journal of English Studies 25 (1), 271286.

Xerri, D. 2019. "Foreword". In Teaching Literature and Language Through Multimodal Texts, edited by E. Domínguez Romero, J. Bobkina, and S. Stefanova, xv-xvi. Hershey, PA: IGI Global.

Zyngier, S. 1994. "At the Crossroads of Language and Literature: Literary Awareness, Stylistics, and the Acquisition of Literary Skills in an EFLit Context". PhD diss., University of Birmingham.

Zyngier, S. and V. Viana. 2016. "Literary Awareness in a High-School EFL Learning Environment: An Empirical Evaluation". In Scientific Approaches to Literature in Learning Environments, edited by M. Burke, O. Fialho, and S. Zyngier, 271-302 Amsterdam: John Benjamins. 
[Type here]

\section{Appendix}

Each workshop unit comprised four sections: 'Setting the scene', 'Food for thought', 'Exploring possibilities' and 'Further exploration'. The following activities were proposed in the first section, which introduced the students to the concept of iconicity at the word level.

(1) Meaning may be reflected through the way words are arranged on the page. Form also contributes to the meanings we make. Look at this example created by a student.

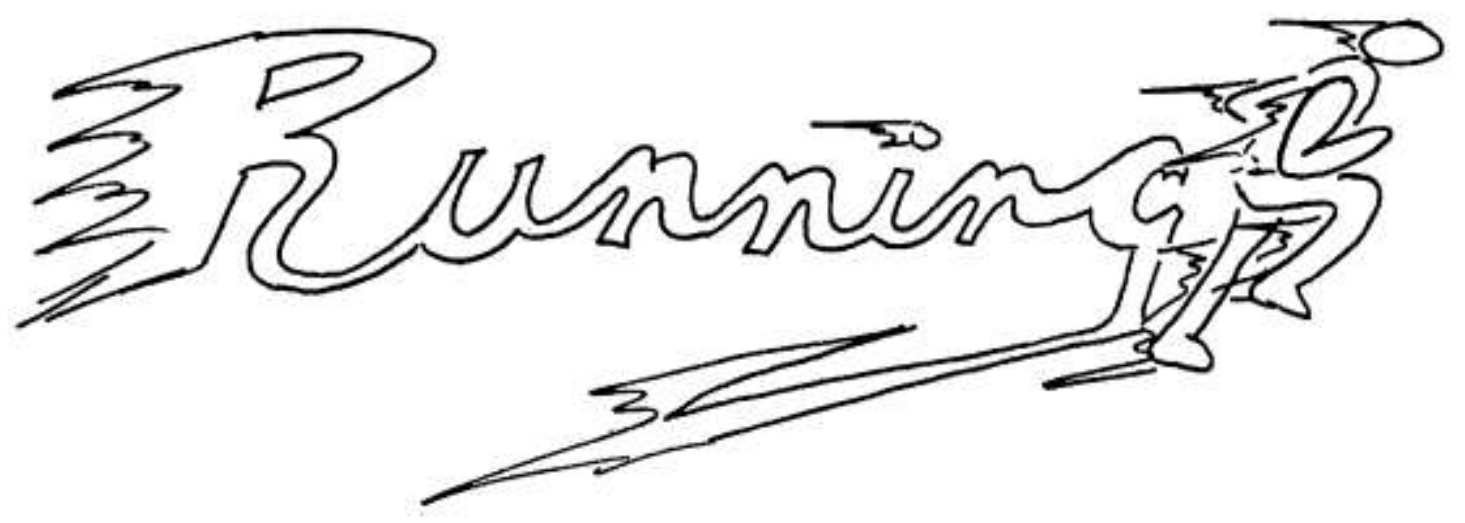

$(\text { OLIVEIRA 1998, 170) })^{1}$

Now answer the following questions.

(a) How are form and meaning linked here?

${ }^{1}$ Oliveira, T. de. 1998. Running. In: Words in Action, edited by S. Zyngier, and R. Gomes, 170. Rio de Janeiro: Gráfica Comunicação. 
[Type here]

(b) Together with a classmate of yours, create a short dialogue between two friends for which this graphic representation would be a suitable illustration. Add as many speeches as you find necessary.

(2) Here is another example by a different student.
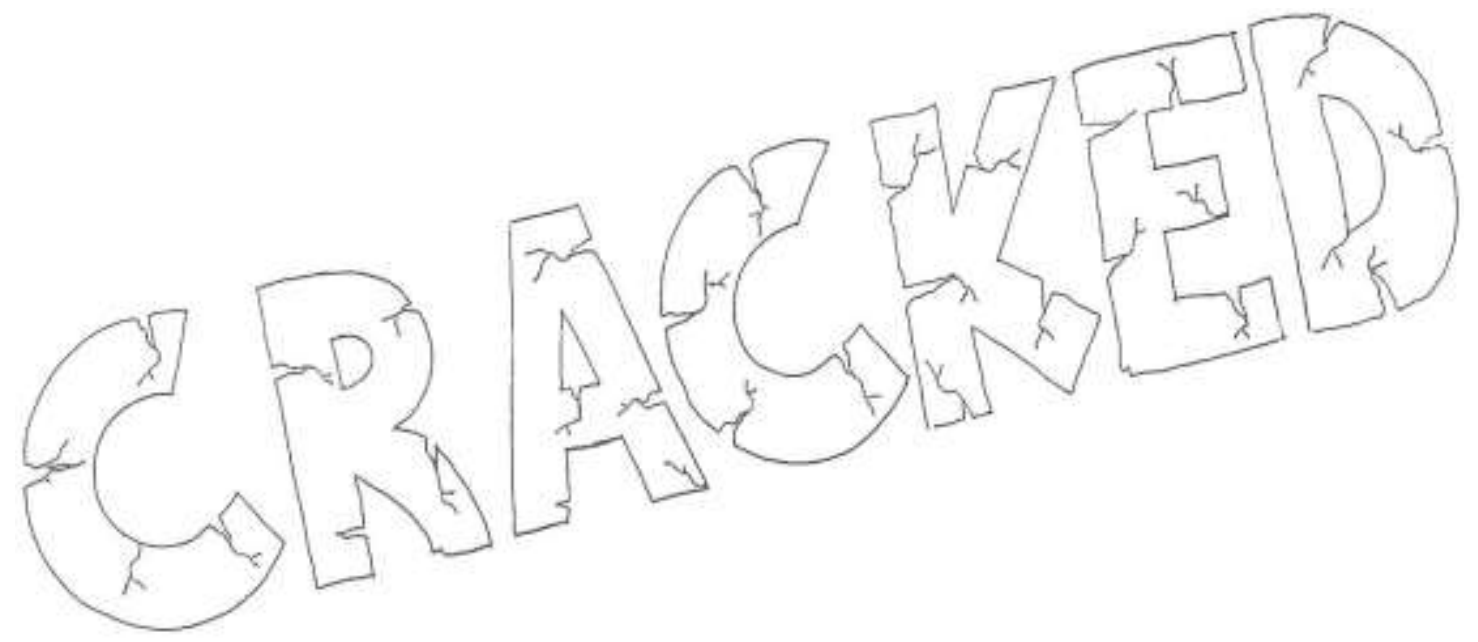

$(\text { FAGUNDES 1998, 185) })^{2}$

(a) How are form and meaning linked here?

(b) Narrate an episode using this sequence as an illustration.

(3) The following picture ${ }^{3}$ can illustrate a text. After you have a look at it, complete the sentences below.

\footnotetext{
${ }^{2}$ Fagundes, F. B. 1998. Cracked. In Words in Action, edited by S. Zyngier, and R. Gomes, 185. Rio de Janeiro: Gráfica Comunicação.

${ }^{3}$ The picture was retrieved from http://encyclopedia.quickseek.com/images/Grawlixes.JPG.
} 
[Type here]

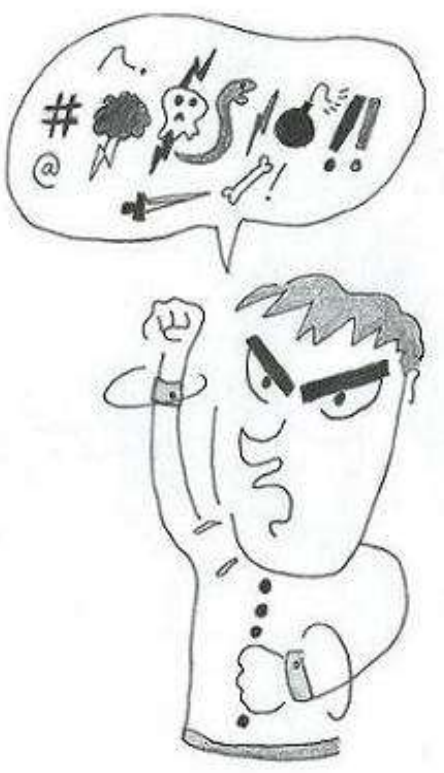

The purpose of this drawing is probably to

(4) Now create your own graphic representation, following the idea of the ones shown in Numbers 1 and 2 above.

(a) Write about your intention to reach your reader here.

(b) Show the graphic representation you have created to a classmate and write down his or her explanation for it.

(c) Compare your classmate's observation with your initial intention. Are they similar? 